\title{
İş Sağlığı ve Güvenliği için IoT Tabanlı Cihaz Tasarımı ve Uygulaması
}

\author{
Çă̆atay Ersin ${ }^{1 *}$, Ali Öz ${ }^{2}$ \\ ${ }^{1}$ Çankırı Karatekin Üniversitesi, Meslek Yüksekokulu, Çankırı, Türkiye (ORCID: 0000-0001-5018-9313) \\ ${ }^{2}$ Mehmet Akif Ersoy Üniversitesi, Teknik Bilimler Meslek Yüksekokulu, Burdur, Türkiye, (ORCID: 0000-0002-0814-4020)
}

(Illk Geliş Tarihi 21 Ocak 2020 ve Kabul Tarihi 9 Mart 2020)

(DOI: 10.31590/ejosat.692616)

ATIF/REFERENCE: Ersin, Ç. \& Öz, Ali. (2020). IoT Based Embedded System Desing and Implementation for Occupational Health and Safety. Avrupa Bilim ve Teknoloji Dergisi, (18), 494-504.

\section{Öz}

IoT (nesnelerin interneti) kavramı nesnelerin bir ağ üzerinden birebirleriyle haberleşmesi olarak tanımlanmaktadır. Nesnelerin interneti ile günümüzde farklı alanlarda birçok çalışma yapılmışıtı. Giderek artan bir şekilde, farklı endüstrilerdeki kuruluşlar verimli çalışmayı arttırmak, daha kaliteli müşteri hizmeti sunmak, karar vermeyi geliştirmek ve işin değerini artırmak, müşterilerle iletişime geçebilmek için nesnelerin interneti teknolojisini kullanmaktadır. Yapılan bu çalışmada iş sağlı̆ı ve güvenliği için IoT tabanlı bir cihaz geliştirilmiştir. Cihaz üzerinde iş güvenliğini, işçi sağlığını ve verimli çalışmayı etkileyen fiziksel koşullar göz önünde bulundurulmuştur. İş yeri için uygun fiziksel koşul parametreleri literatürde taranarak tespit edilmiş̧ir. İşs sağlğ̆ için gerekli optimum fiziksel koşul parametreleri günümüzde yaygın olarak kullanılan arduino uno mikrodenetleyici geliştirme kartına kodlama aşamasında girilmiştir. Tasarlanan sistemde 1sı ve nem sensörü, ldr 1şık sensörü, manyetik alan sensörü, mq7 karbon monoksit gaz sensörü ve ses sensörü kullanılmıştır. Sistem üzerinde bulunan bu sensörler ile CNC dik işleme merkezinin ve freze cihazlarının sıklıkla kullanıldığı bir iş yerinde anlık ölçümler yapılmıştır. Cihaz 2 aylık bir süre ile iş yerinin fiziksel koşul paremetrelerini cihazda bulunan sensörler ile almıştır. Cihaz bu süre içerisinde 3051 veri almıştır. Yapılan bu ölçüm değerleri IoT gerçek zamanlı veri platformu olan thingspeak web sitesine esp8266 wifi modülü ile gönderilmiştir. Thingspeak web sitesine gönderilen veriler bu adreste grafik haline dönüştürülmüş̧ür ve anlık olarak ölçüm sonuçları internet ortamından takip edilmiştir. Bu sistem iş yerinde sabit olarak belirli bir yerde tutulmuş ve iş sağlığı için gerekli fiziksel koşul verilerini sensörler aracıllğıyla ölçüp esp8266 wifi modülü ile web sitesine göndermiştir. Eğer bu parametler optimum değerleri aşarsa sistem iş yerinde dışardan bağlanan bir alarm sayesinde işitsel uyarı verecektir. Ayrıca thingspeak web sitesindeki anlık parametreler android yazılım olan thingview sayesinde akıllı cihazlar ile de takip edilebilmektedir.

\section{IoT Based Device Design and Application for Occupational Health and Safety}

\begin{abstract}
IoT (the internet of things) is defined as the communication of things over the network. It is for working with the Internet of Things for different options today. Increasingly, organizations in different industries are using the Internet of Things technology to communicate with customers to increase efficient work, provide higher quality customer service, improve decision making and ensure business. It is for an IoT based device. It is effective on occupational safety, worker health and efficient work on the device. It is detected by scanning. Aritinoino microcontroller development card is entered in the coding phase. In the designed system, heat and humidity sensor, magnetic field sensor, mq7 carbon monoxide gas sensor and sound sensor detection. With these sensors on the system, it is for instant measurements in a workplace in CNC measurement operations and the requirements of milling devices. The device is associated with the sensors on the physical condition parameters of the workplace for a period of 2 months. The device is for 3051 data during this time. In these measurements, IoT was sent via the esp8266 wifi module on the thingspeak website, which is the data platform of real data. At the Thingspeak web address, it can be converted into a graphic at this address, and instantly the measurement results are followed on the internet. This system is fixed at a certain place in the workplace. If these parameters exceed
\end{abstract}

\footnotetext{
* Sorumlu Yazar: Çankırı Karatekin Üniversitesi, Meskek Yüksekokulu, Elektronik ve Otomasyon Bölümü, Çankırı, Türkiye, ORCID: 0000-00015018-9313, cagatayersin@karatekin.edu.tr
} 
the optimum alarm, the system is for audio warning, thanks to an externally connected alarm at the workplace. You can also follow up with smart devices thanks to the visualization of instant parameters android software on thingspeak websites..

Keywords: IoT, Occupational Health and Safety, Thingspeak, Microcontroller, Sensor, Esp8266

\section{Giriş}

Millions of people in the world are exposed to fatal and non-fatal work accidents every year. According to a recent International Labor Organization (ILO) report, about 2 million workers per year die from occupational accidents. Work accidents can be eliminated by applying current measures and methods. Many industrial countries have comprehensive occupational health and safety (OHS) management systems, and this has been demonstrated by continuously decreasing accident rates [10]. In the past 15 years, the concepts of systematic OHS management and OHS management systems have a wide network among regulators, employers and other parties in developed industrialized countries [11]. Considering the researches on the occurrence of occupational accidents and occupational diseases, it is remarkable that the number of occupational accidents and occupational diseases is at a considerable level [14]. Developing countries are experiencing increasing occupational injuries worldwide. The degree of protection against occupational hazards varies not only by country, but also by the size of the economic sector and enterprise. The highest occupational accident rates occur in the agriculture, forestry, mining and construction sectors, and generally small businesses have a worse safety record than large companies. The economic costs of these injuries and deaths are enormous and cover individuals, initiatives and nations, and even the whole world. In addition to the traditional measures and methods available to protect workers, good OSH systems are systems that constantly update their mechanisms to take account of new risks and hazards that arise in the workplace. In the past decade, the scope, direction and magnitude of OHS have improved significantly both at national and international levels [10].

Occupational work is very important in ensuring worker health and safety and increasing work efficiency. Some of the common features of Industrial organizations, especially in developing countries, are poorly structured jobs, incompatibility between worker abilities and job demands, negative environment, bad human-machine system design and inappropriate management programs. This leads to hazards in the workplace, poor worker health, mechanical equipment injuries, disabilities, which is for employee productivity and product / work. Increasing employee productivity, occupational health, safety and satisfaction in applications of ergonomics or human factors. For this, there are trips and indirect ones on the whole performance in one page. [12]. It would be correct to assume that $80 \%$ of work accidents generally occur due to people, $18 \%$ due to physical and mechanical environmental conditions, and $2 \%$ due to unexpected events. This generalization reveals that approximately $98 \%$ of occupational accidents can take preventive measures [18].

Lighting is one of the most important factors in providing a safe working environment at workplaces, performing visual works easily and creating a suitable field of view. Providing a safe working environment is one of the top priorities and improvement of work safety conditions will be provided by making the hazards in the workplace visible. In addition to the visual effect of illumination, the employee also has biological and psychological effects such as feeling good, high morale and not feeling tired [23]. Employees at workplaces with adequate lighting can see better than those working in poorly lit workplaces and, accordingly, are tired later. If the illumination in the places where work is less than necessary, eye and body fatigue occurs quickly in the employees. This increases the probability of an accident. In a research conducted; If the light intensity in the workplaces is increased from 50 lux to 200 lux, the accident rate has been reduced by $32 \%$. After painting the walls of the same workplace in a light and reflective color, it was observed that there was another $6.5 \%$ decrease in accident rates [18].

Occupational health and safety is defined as the analysis of working conditions, the effects of working conditions on the health and happiness of employees, the reduction of work hazard and risk factors, and the measurement of the effectiveness of these factors [1]. Made works; demonstrated that the air quality, temperature, illumination, noise amount, location, layout and comfort of the working environment are effective in ensuring the productivity of the employees and the efficiency of the working environment [13]. Especially, keeping the humidity levels at high temperatures in workplaces low is very beneficial for work efficiency and health. The amount of moisture should exceed $70 \%$. However, since the humidity level is very low in hot or cold, it will cause dryness in the throat and nose, and it will cause health problems, and the humidity should not fall below a certain rate. The ideal humidity in the workplaces should be $50 \%-60 \%$. In developed industrial countries, it is adopted that the most comfortable ambient temperature is 18.3 degrees in the factories where light physical workers work. Even at this temperature level, it was observed that $1 / 7$ of the employees complain about the heat level. Generally, it has been determined that the upper and lower limits of a workplace environment with suitable working conditions are between 15.6-20 degrees. However, it is not possible for employees to work under this temperature continuously. As the physical activity of the employees increases, it is necessary to decrease the ambient temperature values for a healthy working environment. In heavy industrial works, the ambient temperature limits where the employees feel comfortable are determined as 12.8-15.6 degrees. Workers working against open sources of heat and emitted heat were found to want to work at even lower ambient temperatures [18].

Although noise has very different effects on human health, it can generalize psychological, physiological and performance effects. Psychological effects of noise, behavioral disorders, anger, general discomfort, boredom, temporary or permanent hearing damage, physiological effects; changes in body activity, increase in blood pressure, circulatory disorders, acceleration in breathing, acceleration in heartbeat, sudden reflexes, and performance effects are seen as a decrease in work efficiency, concentration disturbance and inhibition of movements [18]. 


\section{Material and Method}

\subsection{Internet of Things}

The industrial revolution and technological advances are making great progress today. This option is looking for ways to use available businesses technology better and more efficiently. The concept we encounter as an integral part of technology is the internet. The Internet of Things is a popular and widely used concept today [25]. The Internet of Things (IoT) is a network of devices, software and access services that you can use to control and monitor physical events around us. These physical events include production processes, energy networks, patient tracking systems, recycling processes, transportation, smart buildings, shopping, etc. There may be measurable dimensions or control systems such as [1]. "Internet of Things" is required in a presentation that lists the benefits of using RFID (Radio Frequency Identification) technology and recommends it for use [2]. The Internet of Typical Objects architecture consists of 5 basic layers. Detection layer can be used in OSI (Open Systems Connections) model, RFID, ZigBee, QR (Quick Response) code reader etc. Used. It consists of different detection devices and environmental factors. It acquires certain information about all types of sensors in these layers and makes identification. Among the information collected, location, wind speed, vibration, degree of belonging, humidity, temperature, dust ratio in the air, etc. The resulting options are then transferred to the top layer, the network layer [6]. Identification and monitoring / tracking technologies, wired and wireless sensor and activator networks, enhanced communication protocols, and distributed information systems for smart objects are the best known IoT applications. Serious contributions to the advancement of IoT are realized as a result of activities carried out in different fields of knowledge such as social sciences, electronics, informatics and telecommunications [7]. Context-sensitive computing using intelligent connectivity and network resources with existing networks is an indispensable part of IoT. Evolution is already evident towards the ubiquitous information and communication networks, with the increasing availability of WiFi and 4G-LTE (Long Term Evolution) wireless Internet access. However, for the vision of the Internet of Things to emerge successfully, the computing paradigm will have to go beyond traditional mobile computing scenarios using smartphones and portable devices and turn into combining everyday existing objects and putting intelligence in our environment [9]. The activities of companies are shaped by globalization, intense competition and technological developments. The Internet of Things has emerged as a new concept. With this concept, it is expressed that the internet, which is a global communication network, receives information not only from people but also from objects and thus interprets the information it collects and transmits it to other objects and people. Today, almost all of the information entries on the internet are of human origin. With the concept of the Internet of Things that emerged very recently, it is expected that the Internet will lead to a more important and major change from the global impact created by the Internet by communicating not only with people but also with objects [3].

As a result of the establishment of a global neural network in the near future; everyone and everything will be connected. The cloud technology used today can be counted among the steps of this process. As the Internet of Things is part of the daily lives of companies and people, the issue of data security comes to the fore. Data security can have different meanings for individuals and companies. Due to the information shared voluntarily, no material damage or reputation loss is a priority for individuals and companies [3]. With the new developments in technology, a large number of sensor devices can be integrated into the Internet environment via WSN (Wireless Sensor Networks) systems [4]. The Internet of Things provides a widespread worldwide network of uniquely addressable objects and objects in this network to communicate with each other through a specific protocol [5]. The Internet of Things is called the next industrial revolution or the next evolution of the internet. IoT can be defined as an advanced and effective solution for connecting objects to the Internet and collecting data from objects over a network. It will determine how businesses, governments and consumers interact with the physical world through Internet-connected sensors, cameras, handsets, smartphones and other smart IoT devices. IoT is a technological paradigm that aims to increase the connectivity of everyday devices. Therefore, the growth and use of this type of technology will increase exponentially in the coming years due to its application in multiple fields [22]. In this study, an instant measurement device is designed for workplace health and safety. With the designed device, measurement of physical conditions in the workplaces and a healthy and safe working environment were requested. Seven different sensors were used in the device and instant data was obtained from these sensors. Data control and software were provided with the arduino uno microcontroller development board. The data obtained through the sensors were sent to the thingspeak web page used as IoT interface with the esp8266 wifi module. The data are displayed graphically on this web page. Dht 11 heat and humidity sensors, ldr light sensor, hall effect sensor, mq-7 carbon monoxide gas sensor, mq-2 gas sensor and sound sensor were used on the designed device. This designed device has been tried for 2 months in order to receive data in a workplace where CNC vertical machining machines and milling machines are used frequently. The device is installed in a central place at work. The image of the device in the workplace is shown in figure 1. 


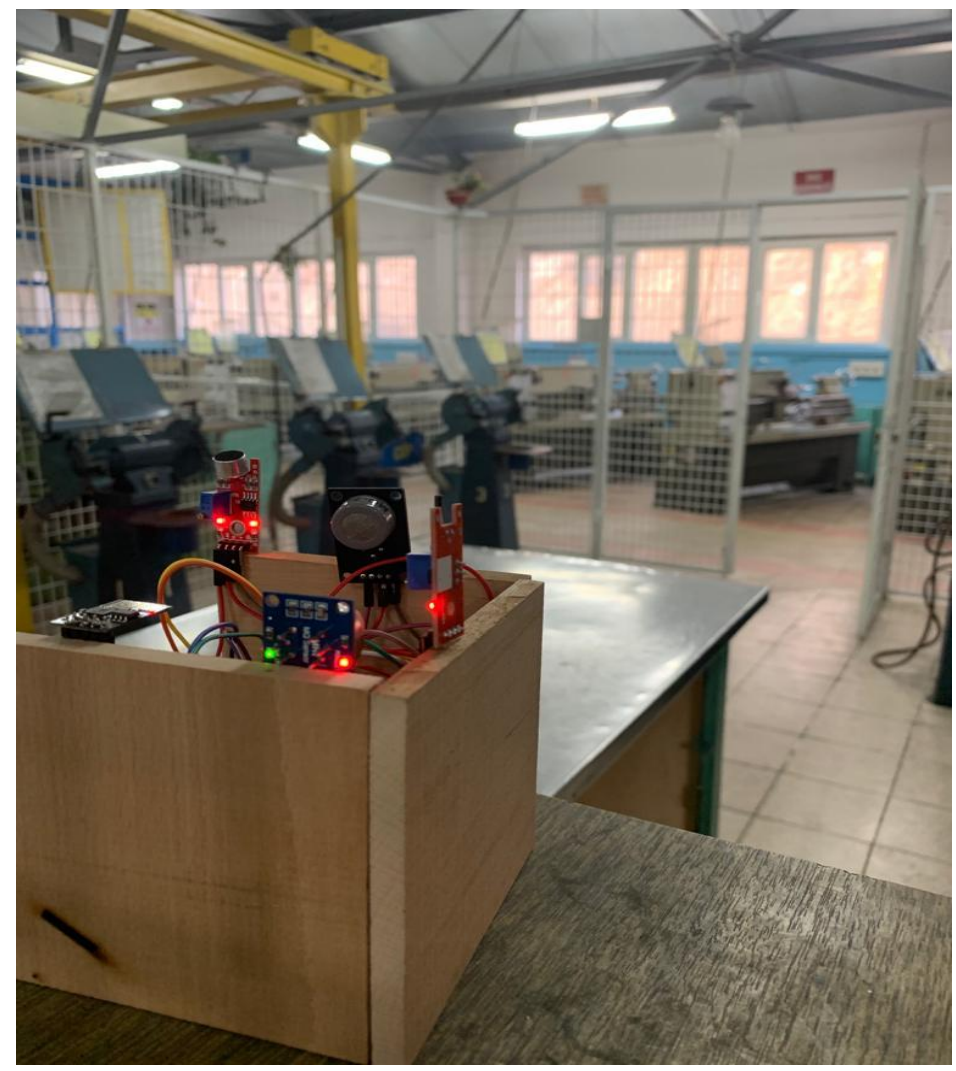

Fig. 1. View of the device at work

With this study, the values taken from the sensors were measured in the workplace, temperature, humidity magnetic field, carbon monoxide gas value, flammable gas and smoke rate, sound and noise level and light amount instantly. The block diagram of the created system is shown in figure 2 .

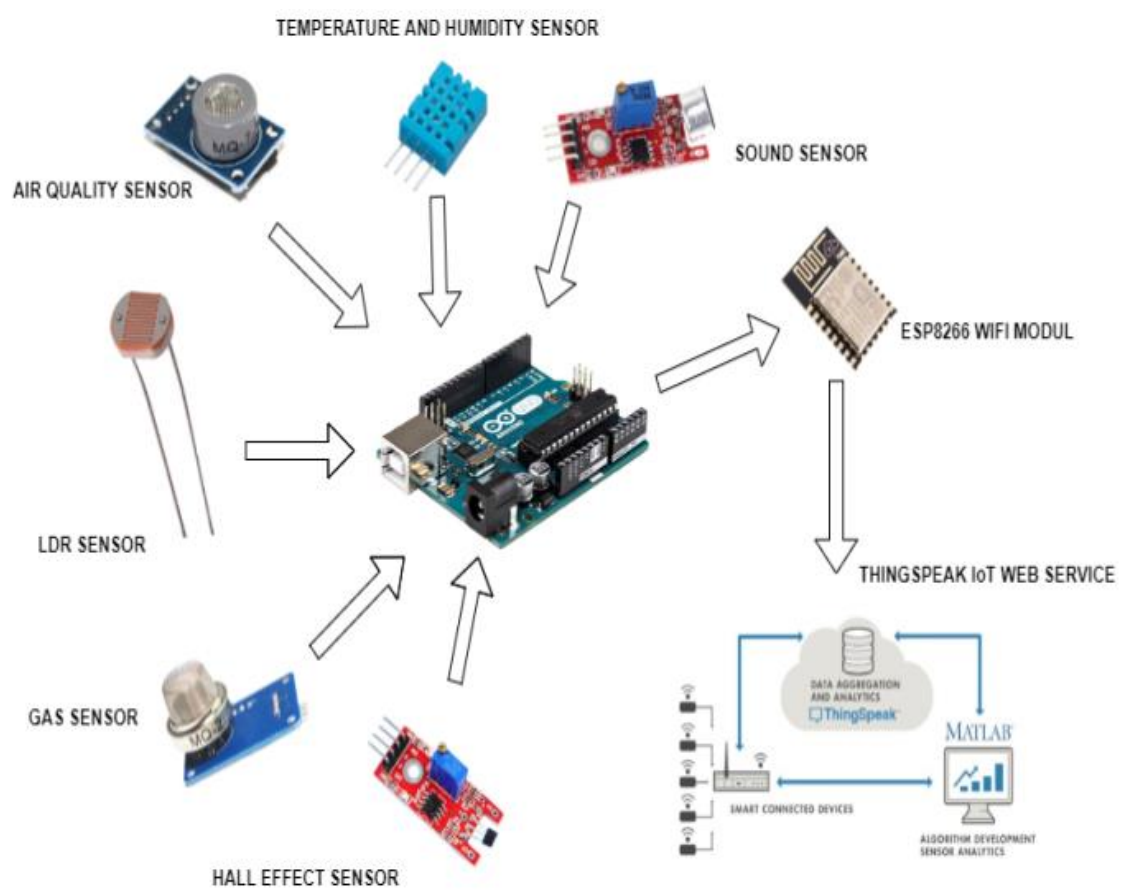

Fig. 2. System block diagram

System simulation and electronic circuit connection has been done. Dht 11 temperature and humidity sensor digital pin is connected to Arduino uno microcontroller development board and other sensors are connected to analog input pins. Tx-Rx connection is made with Esp8266. The electronic circuit connection diagram of the system is shown in figure 3. 


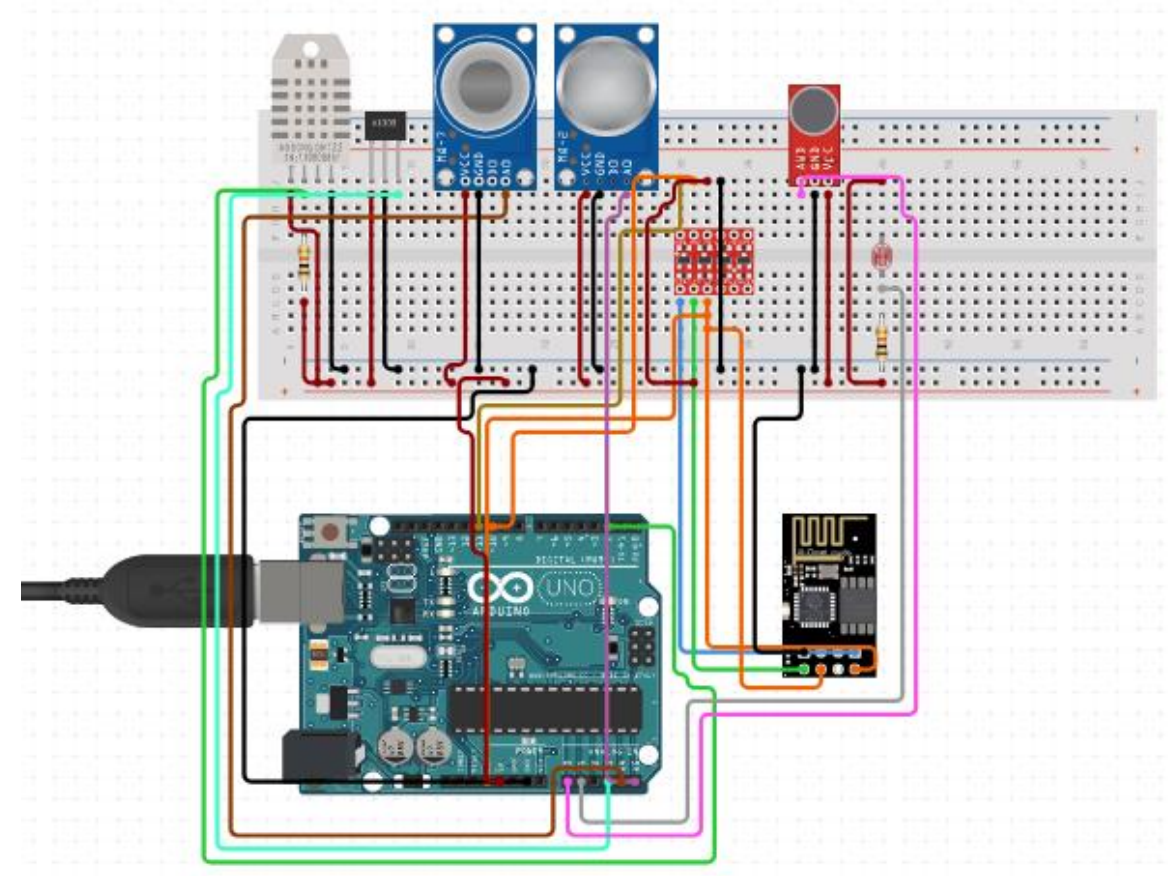

Fig. 3. System electronic circuit connection diagram.

After the electronic circuit connection of the system was made as a simulation, the system was installed on the microcontroller. The designed version of the system is shown in Figure 4.

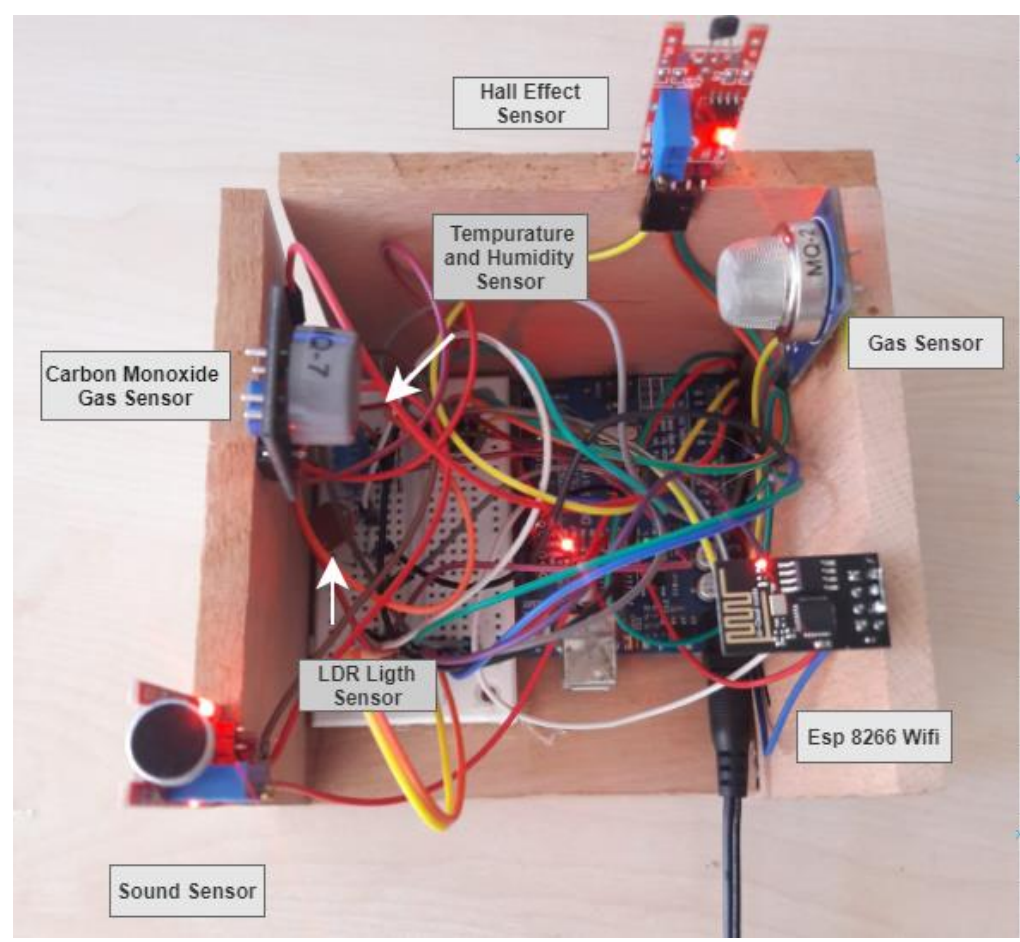

Fig. 4. Image of the system.

\subsection{Esp 8266 Wifi Board}

Wifi modules are used to send data or receive data by connecting to the internet over any wifi line. These modules allow data transfer from Arduino to web servers using the standard HTTP (Hyper Text Transfer Protocol) protocol [21]. ESP8266 is a low cost 
Wifi Module and has ultra low power technology [17]. It is a wifi module supplied by AI Thinker company. ESP8266 can operate in three modes. The first mode is the basic mode. The ESP8266 basic mode is a mode that allows the status of the ESP8266 to be checked to see if it is in good condition. The second mode is layer mode wifi. WiFi ESP8266 layer mode is a mode used when ESP8266 is operating under WiFi condition. The third mode is a TCP (Transmission Control Protocol) layer. TCP layer mode is an ESP8266 mode used when we use an inter-network connection. [19]. The ESP8266 allows fewer external circuits thanks to its highly integrated chip. Includes antenna switch and front-end module designed to minimize PCB space. [24]. ESP8266 is a low cost development board that combines GPIOs, I2C, UART, ADC, PWM and WiFi for rapid prototyping. Powered by 3.3V supply, ESP8266 is packaged as voltage regulator and ESP-12 module from USB to series. Applications can be developed on this board via the Arduino IDE or Lua-based ESPlorer [15]. The ESP8266 module is designed to provide high performance, high integration performance. Shutdown logic and advanced power management provide an energy-efficient Wi-Fi based wireless sensor network. ESP8266 consumes 60uA in deep sleep mode, and the RTC clock is still running and less than $1 \mathrm{~mA}$ to stay connected to the access point. However, if you need an Arduino shield where competing solutions have an edge, for example, the ESP8622 can be programmed with the Arduino IDE and some ESP8266 based shields are available, but probably [16].

ESP-8266 modules should usually be updated before use. For this reason, the update process of ESP-8266 was carried out before the electronic circuit was installed. ESP-8266 connects to the wifi network set in the microcontroller, using the username and password set again in the microcontroller. After the connecting process has been successful; Information from dust, temperature and humidity sensors is sent to the Thinsgspeak analytical IoT platform through this module [21]. Esp82266 wifi module is shown in figure 5 .

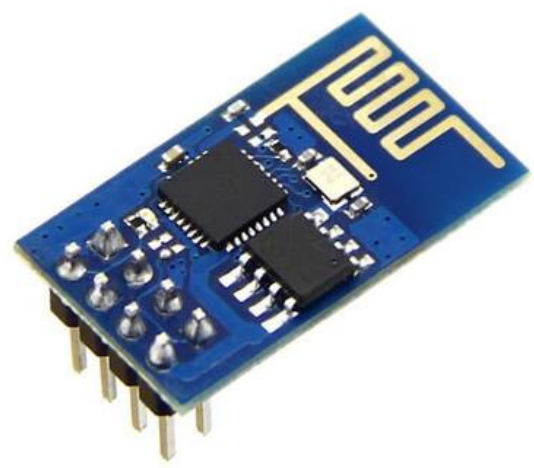

Fig. 5. Esp8266 wifi board

\section{Research Results and Discussion}

\subsection{Thingspeak: A IoT Web Service}

Thingspeak is a free data platform for the Internet of Things (IoT) that remains popular today [25]. Thingspeak is also a webbased open API IoT-based information platform that converts external components used for IoT into their own data and used to store sensor data [20]. Thingspeak communicates between the internet connection and the cloud as a 'data packet' carrier and takes the detected graphic from the connected sensor to the main microcontroller, records, analyzes, observes and works. Thingspeak Arduino, TI CC3200 module, Raspberry-pi etc. It helps build the social network of development photos, sensor-based daily apps, location / location tracking app, and updated objects. The main feature of the Thingspeak function is the Data field, location field, Channel field, which is the status field. Thingspeak, mechanical mechanisms can be created, the information you choose and information can be processed and visualized alternately and matched with MATLAB's use of tweets and other warning forms. It also offers the ability to create a general channel for general analysis and forecasting. It takes advantage of graphic visualization operations for sensors / actuators and can be used for objects. IoT helps bring everything together and allows us to communicate with our own things, and more interestingly, allows objects to interact with other objects. This is the platform. Thingspeak offers the use of real data, graphic visualization, as well as plug-ins used to collaborate with web services, social network or API. The main feature of Thingspeak is the Thingspeak Channel. On a page that will send the channel to Thingspeak for channeling. Programs loaded on the microcontroller transmit to the thingspeak channel within a certain period of time on the sensor screen. Programs uploaded to the microcontroller have a 15-second period to transmit the latest sensor values to the Thingspeak Channel [18]. As the internet of things progressed, the wireless sensor network became more and more acceptable. As the Internet of Things progresses, the wireless sensor network is used. [16].

Production and consumption are increasing in the developing world economy. There are high-capacity machines and workers using these machines in factories, large-scale enterprises. The physical conditions of the workplace must be in suitable conditions under the occupational health and safety laws. The physical conditions of the workplace for the healthy and productive working environments of the workers have been scanned in the literature for temperature, humidity, magnetic field, sound level, flammable gas value, carbon monoxide gas value. These values can be monitored on the thingspeak web interface by the occupational safety specialist or business owner. The maximum and minimum values of the data sent are shown at the bottom of the graphs as well as the last data received. Thus, the occupational safety specialist will be able to see the values that affect the physical conditions in the 
workplace with this web interface. In addition, these values and created graphics can be followed with the android device with the android based thingview program. The images of the graphics are shown in figures 6 and 7 through the thingview program.

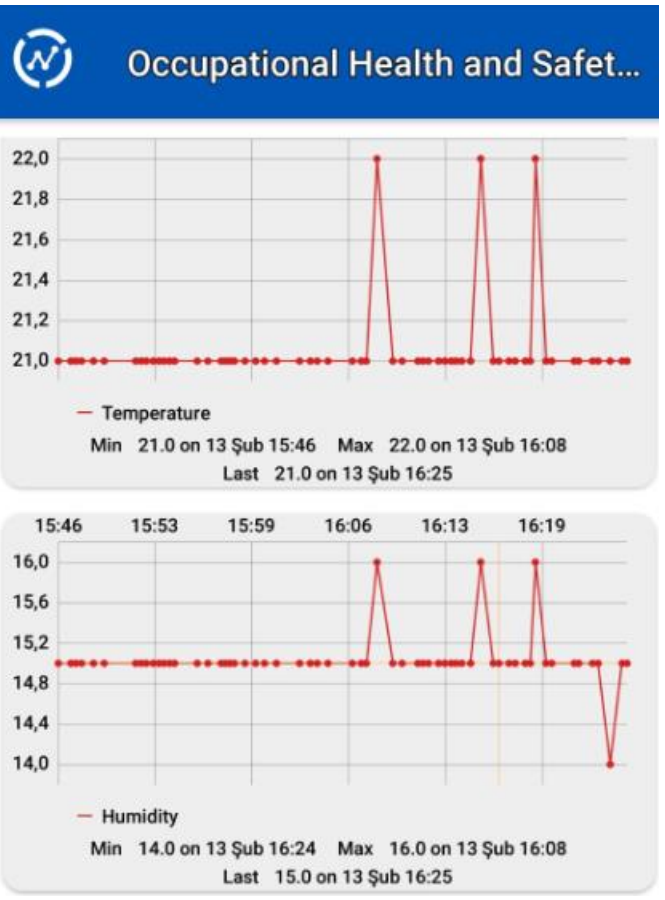

Fig. 6. Thingview Program Screenshot I
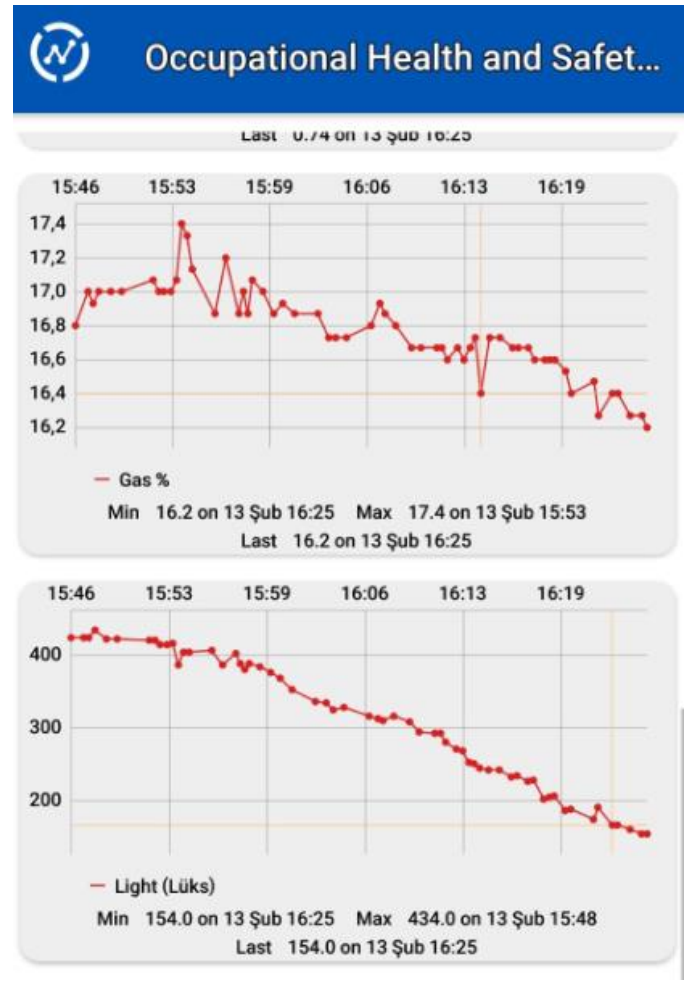

Fig. 7. Thingview program screenshot II

The system is programmed with the arduino uno microcontroller development board ide software. The data of the designed system is displayed numerically from the com port of the arduino ide software. The esp8266 wifi module has been added to the Arduino uno microcontroller development board. The flow diagram of the created software is shown in figure 8 . 
European Journal of Science and Technology

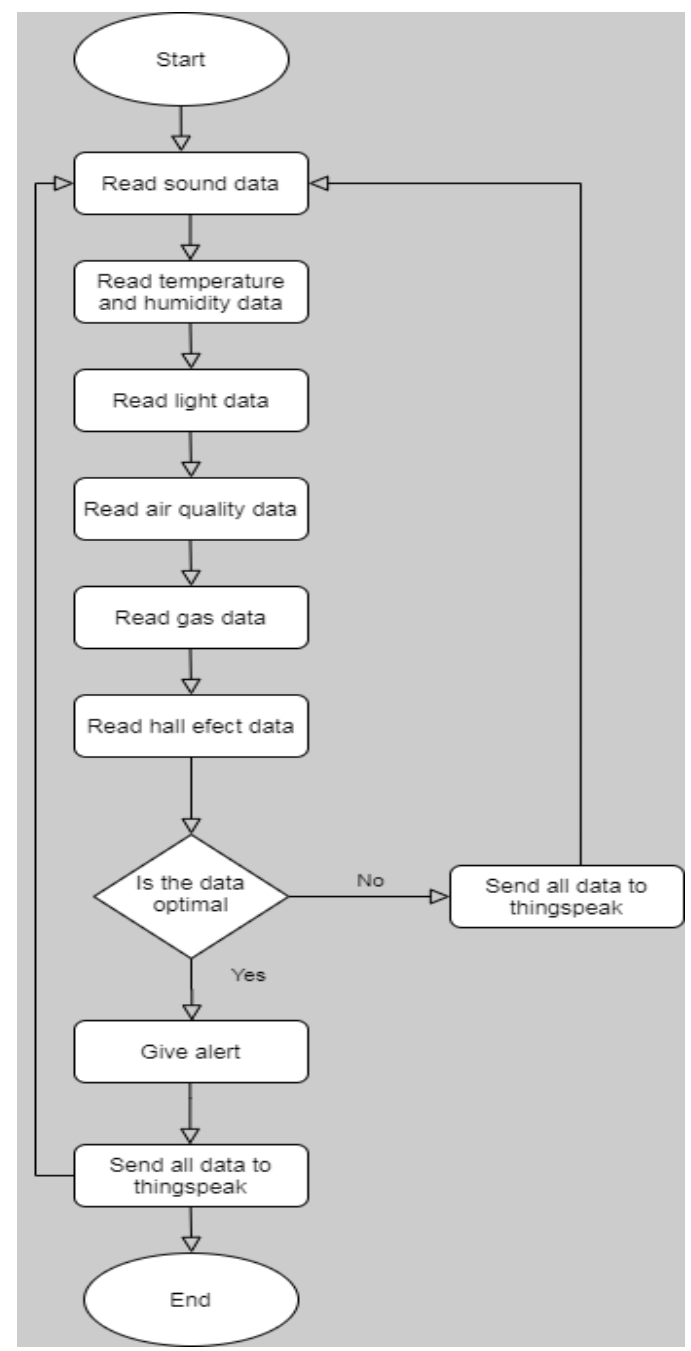

Fig. 8. Flow chart of the system

The graphical image of the data sent by the occupational health and safety device designed in the study in the thingspeak web interface is shown in figures 9-15.

\section{Channel Stats}

Created: 2 months ago

Last entry: 23 minutes agoo

Entries: 3051

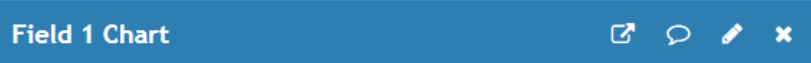

Fig. 9. Thingspeak temperature view 


Field 2 Chart $\quad$ ¿ 0

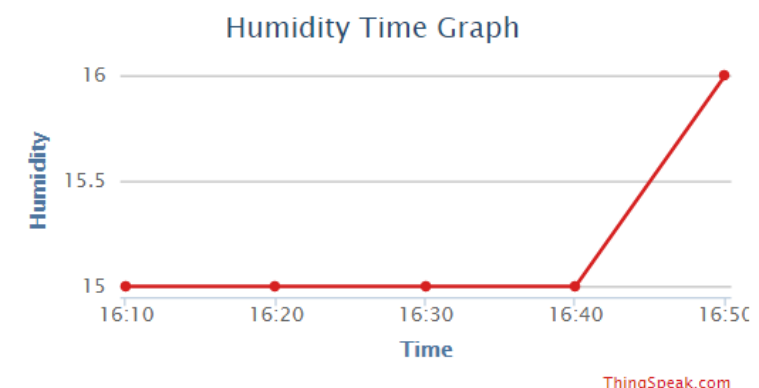

Fig. 10. Thingspeak humidity view

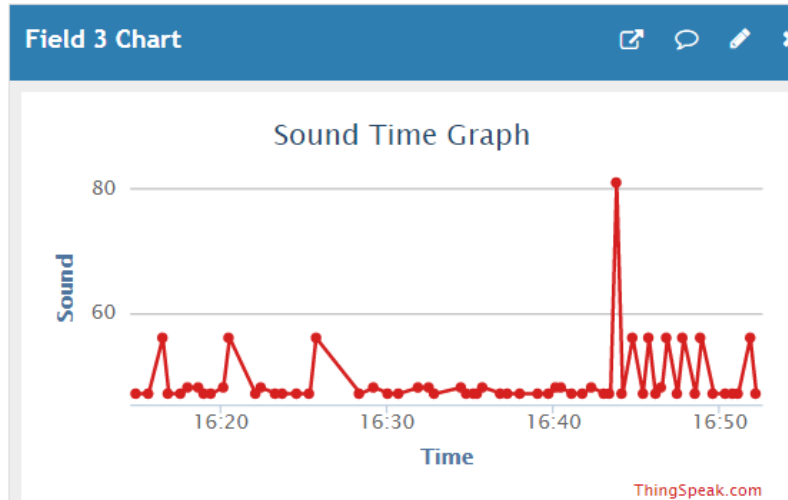

Fig. 11. Thingspeak sound view.

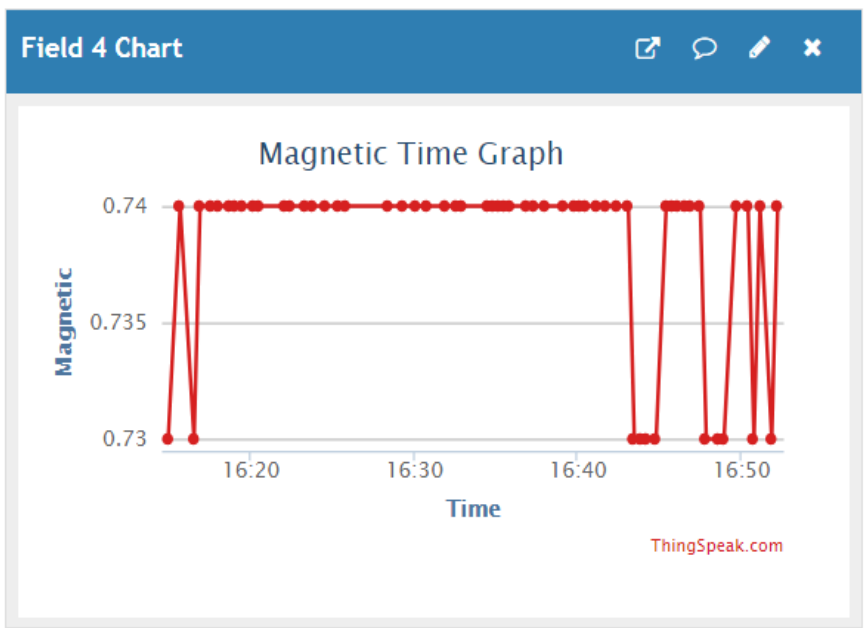

Fig.12. Thingspeak magnetic view 


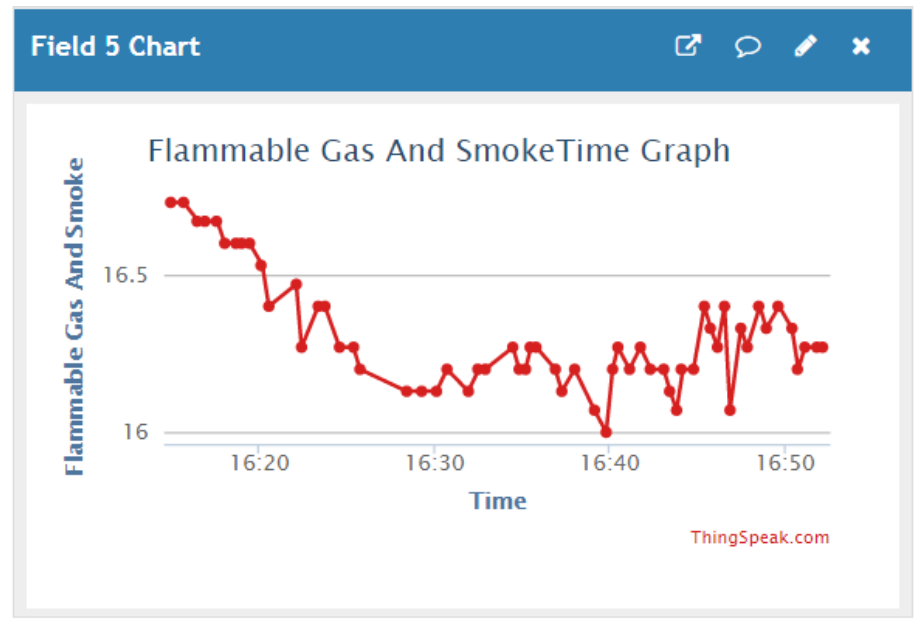

Fig. 13. Thingspeak flammable gas and smoke view

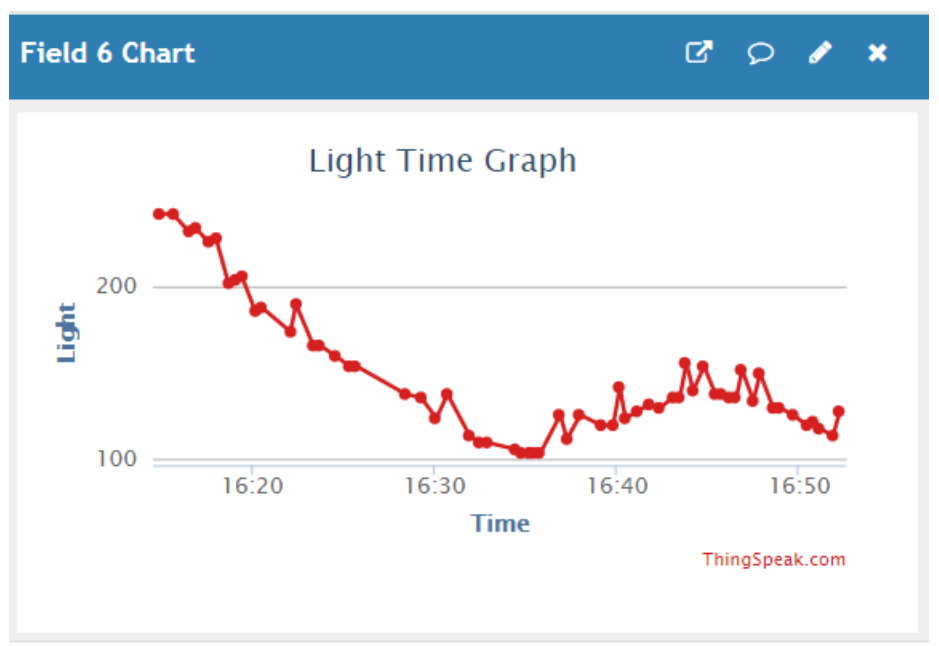

Fig. 14. Thingspeak light view
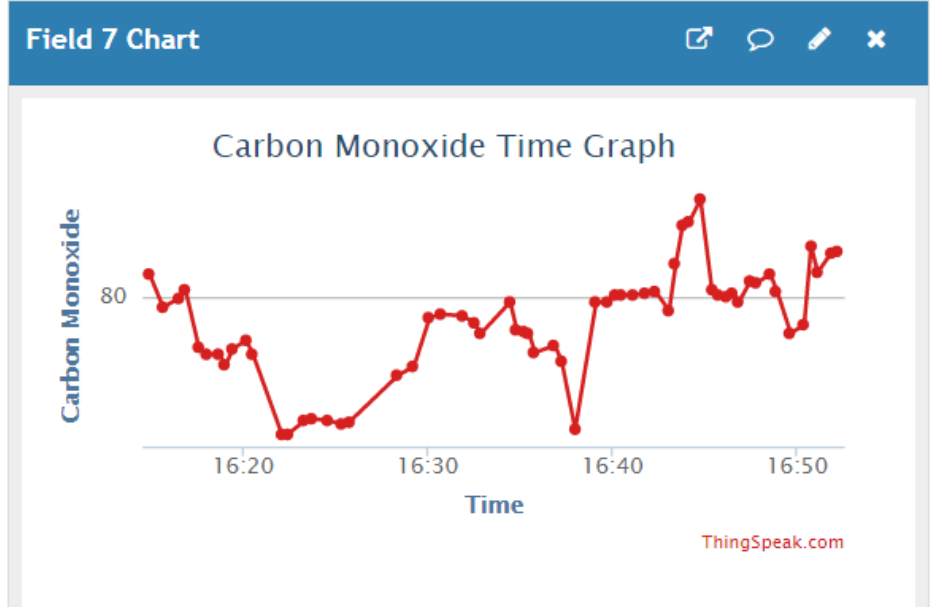

Fig. 15. Thingspeak carbon monoxide view.

\section{Result}

The internet concept of objects is finding itself more and more application areas. Many products we use in daily life are connected and communicated via the internet. These devices can be easily tracked through android devices, tablets, personal computers and smart phones that people use widely. In the scanned literature, it has been observed that the internet concept of objects is widely used in many areas, but not many studies on occupational health and safety have been identified. This designed work was carried out on the increasing importance of the concept of occupational health and safety in the developing world industry. Physical environmental 
conditions for occupational health and safety have been searched from the literature and the device has been coded in accordance with these parameters. The control of the system was made with the microcontroller development board of the arduino flour, which is widely used today. Within the scope of occupational health and safety, parameters such as temperature, humidity, carbon monoxide ratio, flammable gas value, noise and light were measured by sensors. The device instantly received data from these sensors and sent it in the thingspeak IoT interface. The device was tested at a workplace for a period of 2 months and 3051 data was received. The data received were measured as average $21 \mathrm{C}^{\circ}$ for temperature, average humidity of $16 \mathrm{~g} / \mathrm{m}^{3}$, noise value of 60 decibels, average light value of the workplace 160 lux, flammable gas value of $16.5 \%$ magnetic field average of 0.73 and carbon monoxide gas average of 80 ppm (parts per million). The system received data with seven different sensors in its designed state. It can be developed to add more sensors to the system and to alert the occupational safety specialist by e-mail or sms when these physical conditions exceed the optimum level.

\section{References}

[1] Gökrem, L., Bozuklu, M., Nesnelerin İnterneti:Yapılan Çalışmalar ve Ülkemizdeki Mevcut Durum, Gaziosmanpaşa Bilimsel Araştırma Dergisi, P 47-68, 2016, Tokat.

[2] Aktaş, F., Çeken, C., Erdemli, Y., E., Biyomedikal Uygulamaları için Nesnelerin İnterneti Tabanlı Veri TOplama ve Analiz Sistemi, Tip Teknolojileri Ulusal Kongresi, 2014, Kapadokya.

[3] Erturan, E., İ.,Ergin, E., Muhasebe Denetiminde Nesnelerin İnterneti:Stok Döngüsü, The Journal of Accounting and Finance, Temmuz, 2017.

[4] Ercan, T., Kutay,, M., Endüstride Nesnelerin Interneti (IoT) Uygulamaları, Afyon Kocatepe Üniversitesi Fen ve Mühendislik Bilmleri Dergisi,P 599-607, 2016.

[5] Oral, O., Çakır, M., Nesnelerin İnterneti Kavramı ve Örnek Bir Prototipn Oluşturulması, Mehmet Akif Üniversitesi Fen Bilimleri Enstitüsü Dergisi,P 172-177, 2017.

[6] Arslan, K.,Kırbaş, İ.,Nesnelerin İnterneti Uygulamaları için Algılayıcı/Eyleyici KAblosuz Düğüm İlkörnek Geliştirme, Mehmet Akif Üniversitesi Fen Bilimleri Enstitüsü Dergisi, P35-43, 2016.

[7] Gündüz, Z., M., Daş, R., Internet of Things(IoT): Evolution, Components and Applications Fields, Pamukkale Üniversitesi Mühendislik Bilimleri Dergisi, P 327-335, 2018.

[8] Pasha, S., Thingspeak Based Sensing and Monitoring System for IoT with Matlab Analysis, P19-23,2016.

[9] Gubbi, J.Vd, Internet of Things(IoT): A vision, architectural elements and future directions, Future Generation Computer Systems, P 1645-1660, 2013.

[10] Alli, B., O., Occupational safety and health: A global perspective, Fundamental principles of occupational health and safety Second edition, 2017.

[11] Kaj, F., Occupational safety and health: A global perspective, Middlesex University Res, 14.01.2020.

[12] Shikdar, A., A., Sawaqed, N., M., Workerproductivitiy, and occupational health and safety issues in selected industries, Computer\&Industrial Engineering, P 563-572, 2003.

[13] Hoşten, G., Yalbay, N., Kapalı Ortam Hava Kalitesinin Ofis Ortamlarında İş Sağlığı ve Güvenliği Açısından Değerlendirilmesi, Aydın Sağlık Dergisi P 1-12, 2018.

[14] Karacan, E., Erdoğan, ö., N., İşçi Sağlığı ve Güvenliğine İnsan Kaynakları Yönetimi Fonksiyonları Açısından Çözümsel Bir Yaklaşım, Kocaeli Üniversitesi Sosyal Bilimler Enstitüsü Dergisi P 102-116, 2011.

[15] Kodali, R., K., Soratkal, S., R., MQTT based Home Automation System Using ESP8266, IEEE Region 10 Humanitarian Technology Conference, 2016.

[16] Thaker, T., ESP8266 Based Implementation of Wireless Sensor Network with Linux Based Web-Server, 2016 Symposium on Colossal Data Analysis and Networking(CDAN), 2016.

[17] Kodali, R., K., Mahesh, K., S., Low Cost Ambient Monitoring using ESP8266, 2nd International Conference on Contemporary Computing and Informatics, 2016.

[18] Camkurt, Z., M., İşyeri Çalışma Sistemi ve İşyeri Fiziksel Faktörlerinin İş Kazaları Üzerindeki Etkisi, TÜHİS İş Hukuku ve İktisat Dergisi, 2007.

[19] Wibowo, S., F.,Pribadi, A., B., Internet Of Things Experiment Using Esp8266 Wifi Module, Thingspeak Channel And Delphi Interface, International Symposium for Modern School Development, Social Science and Applied Technologies (ISMOSAT 2016), Grand Sakinah Mayong Jepara, 19 - 20 March 2016.

[20] Samsugi, S., Ardiamsyah, Kastura, D., Arduino Dan Modul Wifi Esp8266 Sebagai Media Kendali Jarak Jauh Dengan Antarmuka Berbasis Android, Jurnal Teknoinfo, P 23-27,2018.

[21] Karacı, A., Akıllı Şahir Hava Takip Sistemi ve Astım Hastaları için PM2.5 Konsantrasyonu Ölçüm Aracının geliştirilmesi, Mühendislik Bilimleri ve Tasarım Dergisi, P 418-425, 2018.

[22] Kelebekler, E., Nesnelerin İnterneti Tabanlı Meteorolojik Veri Takip Sistemi, Düzce Üniversitesi Bilim ve Teknoloji Dergisi, P 650-663, 2019.

[23] Kürkçü, E., A., Çakar, İ., Zeyrek, S., İşyerinde Aydınlatma, İş Sağlığı ve Güvenliği Merkezi Müdürlüğü.(İSGEM), Date of Access:11.10.2019.

[24] Srivastava, P., Bajaj, M., Rana, A., S., IoT Based Controlling of Hybrid Energy System using ESP8266, IEEMA Engineer Infinite Conference, 2018.

[25] Ç.Ersin, M.Yaz, M.Karhan ‘An Example IoT Application for the Defense Industry’, Elec Lett Sci Eng, vol. 15(3) , (2019), 66-73. 